\title{
Effects of aquatic vegetation type on denitrification
}

\author{
Annelies J. Veraart • Wilco J. J. de Bruijne • \\ Jeroen J. M. de Klein - Edwin T. H. M. Peeters • \\ Marten Scheffer
}

Received: 2 November 2009/ Accepted: 19 June 2010/Published online: 6 July 2010

(C) The Author(s) 2010. This article is published with open access at Springerlink.com

\begin{abstract}
In a microcosm ${ }^{15} \mathrm{~N}$ enrichment experiment we tested the effect of floating vegetation (Lemna sp.) and submerged vegetation (Elodea nuttallii) on denitrification rates, and compared it to systems without macrophytes. Oxygen concentration, and thus photosynthesis, plays an important role in regulating denitrification rates and therefore the experiments were performed under dark as well as under light conditions. Denitrification rates differed widely between treatments, ranging from 2.8 to $20.9 \mu \mathrm{mol} \mathrm{N} \mathrm{m}{ }^{-2} \mathrm{~h}^{-1}$, and were strongly affected by the type of macrophytes present. These differences may be explained by the effects of macrophytes on oxygen conditions. Highest denitrification rates were observed under a closed mat of floating macrophytes where oxygen concentrations were low. In the light, denitrification was inhibited by oxygen from photosynthesis by submerged macrophytes, and by benthic algae in the systems without macrophytes. However, in microcosms with floating vegetation there was no effect of light, as the closed mat of floating plants caused permanently dark conditions in the water column. Nitrate removal was dominated by plant
\end{abstract}

A. J. Veraart $(\bowtie)$. W. J. J. de Bruijne .

J. J. M. de Klein - E. T. H. M. Peeters · M. Scheffer

Department of Aquatic Ecology and Water Quality

Management, Wageningen University, PO Box 47,

6700AA Wageningen, The Netherlands

e-mail: Annelies.Veraart@wur.nl uptake rather than denitrification, and did not differ between systems with submerged or floating plants.

Keywords Denitrification - Ditches ·

Floating plants $\cdot$ Macrophytes $\cdot$ Nitrogen

\section{Introduction}

Nitrogen inputs to aquatic ecosystems have dramatically increased in the past decades. Excess nutrient loading has caused numerous problems in aquatic ecosystems worldwide, such as harmful phytoplankton blooms, closed mats of floating plants, hypoxia and loss of biodiversity (Scheffer et al. 2003; Smith et al. 1999). Denitrification, the reduction of nitrate to gaseous nitrogen, is an important process for permanent nitrate removal from aquatic systems (Seitzinger et al. 2006). It occurs under anoxic conditions and requires the presence of sufficient nitrate and organic carbon (Knowles 1982). In aquatic ecosystems, denitrification mainly takes place in the sediment (Eriksson and Weisner 1999), but it also occurs in biofilms on macrophyte surfaces (Eriksson 2001; Eriksson and Weisner 1999; Körner 1999).

Macrophytes may influence denitrification rates directly and indirectly. Directly, they provide surface area for attached biofilms, where the heterogeneous oxygen conditions may favor both nitrification and denitrification (Eriksson and Weisner 1996, 1999; Körner 1999), although most surface area will be 
available in the sediment itself where conditions are more suitable for denitrification. Indirectly, they affect denitrification rates by changing the nutrient concentrations by uptake and release during growth and senescence, and by influencing oxygen levels, $\mathrm{pH}$ and organic carbon availability in the sediment and the water column (Carpenter and Lodge 1986; Körner 1999; Weisner et al. 1994).

In this way, rooted submerged macrophytes may create favorable conditions for coupled nitrificationdenitrification in the sediment by creating heterogeneous oxygen conditions in the root zone, and by excreting organic carbon from their roots (Caffrey and Kemp 1992; Christensen and Sorensen 1986; Reddy et al. 1989; Weisner et al. 1994). On the other hand, submerged macrophytes may inhibit denitrification when photosynthesis generated oxygen levels become too high, and by competing for nitrate with denitrifying bacteria (Toet et al. 2003; Weisner et al. 1994).

There are thus both negative and positive effects of macrophytes on denitrification. A meta-analysis of 136 data-sets showed no significant difference in denitrification rates in absence or presence of macrophytes (Piña-Ochoa and Álvarez-Cobelas 2006). However, this study was done on datasets gathered in systems with different types of vegetation, which may have different effects on denitrification, and in sites with various environmental conditions. Several direct comparisons of denitrification rates in vegetated and nonvegetated sediment patches showed positive effects of macrophytes on denitrification (Caffrey and Kemp 1992; Christensen and Sorensen 1986; Iizumi et al. 1980). However, the effect of the type of vegetation, either floating or submerged, on denitrification is still unclear. Studying the effects of these vegetation types on denitrification is particularly interesting as many shallow waterbodies such as ditches and ponds are dominated by either submerged or floating vegetation, depending on nutrient loading (Janse and Van Puijenbroek 1998; Scheffer et al. 2003).

In this study we compared the effect of floating macrophytes (Lemna sp.) and submerged macrophytes (Elodea nuttallii (Planch.) H. St John) on total denitrification rates in a microcosm experiment. We included microcosms without macrophytes to study effects of macrophyte presence. To explore the effect of photosynthesis-driven variation in oxygen levels, we performed the experiments both under light and dark conditions.

\section{Methods}

Experimental setup

Eighteen microcosms ( 8 1 v., $20 \mathrm{~cm} \emptyset, 30 \mathrm{~cm} \mathrm{~h}$ ) were used, in which we introduced a $2 \mathrm{~cm}$ thick layer of sediment $(330 \mathrm{ml})$ and 71 of Smart and Barko macrophyte growth medium with $1 \mathrm{mg} \mathrm{N} / \mathrm{l}$ and $0.19 \mathrm{mg}$ P/l (Smart and Barko 1985; van Liere et al. 2007). The sediment contained $7 \%$ organic matter and originated from a nearby eutrophic pond. We applied 3 treatments to the microcosms with 6 replicates each: they were either covered completely by the floating macrophyte duckweed (Lemna sp.) (corresponding to ca. $5.3 \mathrm{~g}$ dry weight), filled with $70 \mathrm{~g}$ wet weight of the submerged macrophyte western waterweed (Elodea nuttallii (Planch.) St. John) (corresponding to $4.5 \mathrm{~g}$ dry weight), or kept without vegetation. We chose these species as they are representative types of floating and submerged vegetation in mesotrophic and eutrophic ditches and lakes, and dominate many waterbodies in the Netherlands. Waterweed was collected in a nearby mesotrophic artificial drainage ditch (Sinderhoeve Experimental Station, Renkum, The Netherlands $51^{\circ} 59^{\prime} 55.08^{\prime \prime} \mathrm{N}, 5^{\circ} 45^{\prime} 21.40^{\prime \prime} \mathrm{E}$ ). Duckweed was collected in a nearby eutrophic drainage ditch (Wageningen, The Netherlands $51^{\circ} 59^{\prime} 14.29^{\prime \prime} \mathrm{N}, 5^{\circ} 45^{\prime} 21.40^{\prime \prime} \mathrm{E}$ ). We kept all macrophytes on Smart and Barko growth medium at $20^{\circ} \mathrm{C}$ for 4 weeks, and removed all visible snails before placing them into the microcosms.

The microcosms were incubated for 4 weeks in a water bath at $20.5 \pm 0.9^{\circ} \mathrm{C}$ at a $12 \mathrm{~h} / 12 \mathrm{~h}$ light/dark cycle to ensure biofilm development. After the incubation period denitrification was measured. We measured denitrification in 3 microcosms of each treatment during light conditions after a light period of $4 \mathrm{~h}$, and in the remaining 3 under dark conditions after a dark period of $8 \mathrm{~h}$. The experiment was run twice, leading to a total of 36 measurements.

Water quality analysis

Oxygen, $\mathrm{pH}$, temperature and electric conductivity were measured with a HQ multiprobe with a luminescent dissolved oxygen sensor (Hach Company, Loveland, Colorado, USA) directly before the denitrification measurements. We took 3 water samples from each microcosm directly before and after the denitrification measurements. Two samples were 
filtered immediately with a Whatman $0.45 \mu \mathrm{m}$ cellulose membrane filter (Whatman International Ltd, Maidstone, England) and then frozen until analysis. The other one was left unfiltered. Filtrated samples were analysed colorimetrically for $\mathrm{NO}_{3}{ }^{-}+\mathrm{NO}_{2}{ }^{-}$, $\mathrm{NH}_{4}{ }^{+}$and ortho- $\mathrm{PO}_{4}{ }^{3-}$, using a SAN ${ }^{\text {plus }}$ autoanalyzer (Skalar Analytical, Breda, The Netherlands). Nitrate and nitrite (hereafter: nitrate) were determined by the sulfanilamide/naphthylethylene-diamine dihydrochloride method with cadmium reduction (Green et al. 1982), ammonium by the indophenol blue method (Bietz 1974), and ortho-phosphate using the ammonium-molybdate method (Murphy and Riley 1962). Chlorophyll- $a$ was determined by Pulse Amplitude Modulation fluorometry (Phyto-PAM) in the unfiltered samples immediately after collection, as described by Lürling and Verschoor (2003).

Light irradiance at the sediment surface in the microcosms was measured before the denitrification measurements with a subsurface light intensity meter (LI-COR, Lincoln, NE, USA). Water losses due to evaporation and sampling were compensated for by adding deionized water.

\section{Denitrification measurements}

For the denitrification measurements the microcosms were closed with airtight lids. Each lid had a screw opening for a stirrer and a screw cap-opening with a septum. The lids were positioned $4 \mathrm{~cm}$ under the water surface, gently pushing down the macrophytes (Fig. 1). The growth medium under the lids of the microcosms was enriched with $1.07 \mathrm{mg} / \mathrm{l}^{15} \mathrm{~N}$ by injecting $0.5 \mathrm{mmol} / 1{ }^{15} \mathrm{~N}\left[\mathrm{Na}-\mathrm{NO}_{3}\right]$ (98 at.\%) through

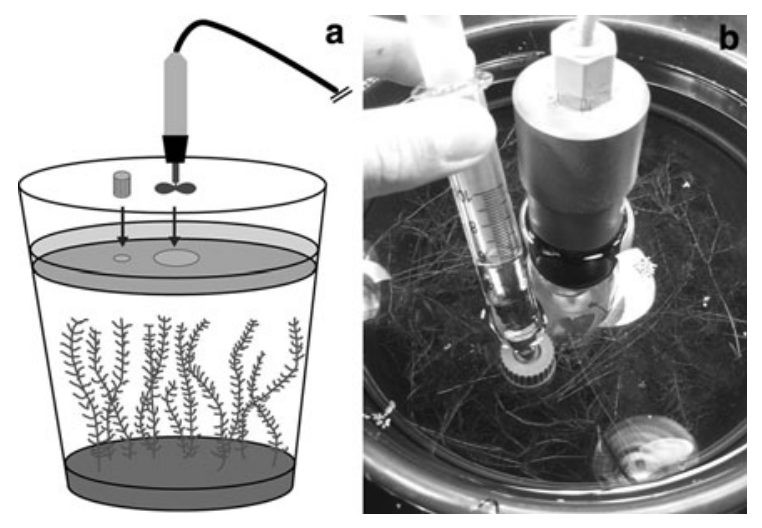

Fig. 1 Schematic overview (a) and picture (b) of a microcosm containing E. nuttallii the septum. We added $0.5 \mathrm{mg} / \mathrm{l}$ glucose as a source of easily oxidisable carbon to prevent carbon limitation of the denitrifying bacteria during the denitrification measurements. Water was sampled $0.25,1,2$ and $3 \mathrm{~h}$ after injection of the ${ }^{15} \mathrm{~N}\left[\mathrm{Na}-\mathrm{NO}_{3}\right]$ solution. Water samples $(5 \mathrm{ml}$, in triplicate) were taken through the septum using a $5 \mathrm{ml}$ airtight glass syringe, and were injected into $12 \mathrm{ml}$ exetainers (Labco, High Wycombe, UK). Exetainers contained $100 \mu \mathrm{l} 50 \%$ (w:v) $\mathrm{ZnCl}_{2}$ solution to stop biological processes in the samples, and were pre-flushed with helium to prevent air contamination, after which $5 \mathrm{ml}$ of helium was removed to create space for the water sample (Dalsgaard et al. 2000). Samples were stored at room temperature and before analysis they were vigorously shaken to transfer the dissolved $\mathrm{N}_{2}$ into the helium headspace. Dinitrogen concentrations and ratios of ${ }^{14,15} \mathrm{~N}_{2}$ and ${ }^{15,15} \mathrm{~N}_{2}$ over ${ }^{14,14} \mathrm{~N}_{2}$ were measured using a SerCon Cryoprep trace gas concentration system interfaced to a PDZ Europa 20-20 isotope ratio mass spectrometer (Sercon Ltd., Cheshire, UK) at the UC Davis stable isotope facility (Davis, CA, USA). We calculated denitrification rates from the change in ratios of ${ }^{14,15} \mathrm{~N}_{2} /{ }^{14,14} \mathrm{~N}_{2}$ and ${ }^{15,15} \mathrm{~N}_{2} /{ }^{14,14} \mathrm{~N}_{2}$ in time, following Nielsen (1992).

\section{Nitrate removal}

Nitrate removal rates $R_{T}\left(\mathrm{mg} \mathrm{N}^{-1} \mathrm{~h}^{-1}\right)$ were calculated from the difference between the nitrate concentration in the microcosm before the denitrification measurements $\left(N_{t=0)}\right.$ and after the denitrification measurements $\left(N_{t=\mathrm{t}}\right)$ using Eq. 1:

$R_{T}=\frac{N_{t=0}-N_{t=t}}{t}$

where $t$ is the duration of the denitrification measurements (h). Nitrate removed from the microcosm by denitrification $\left(R_{D}, \mathrm{mg} \mathrm{N}^{-1} \mathrm{~h}^{-1}\right)$ was calculated as:

$R_{D}=\frac{D \cdot M \cdot A \cdot t}{V}$

where $D$ is the denitrification rate $\left(\mathrm{mmol} \mathrm{N} \mathrm{m} \mathrm{m}^{-2}\right.$ $\left.\mathrm{h}^{-1}\right), M$ is the molar mass of nitrogen $(\mathrm{g}), A$ is the microcosm area $\left(\mathrm{m}^{2}\right), t$ is the duration of the experiment (h) and $V$ is the microcosm volume (l). Percentage of $\mathrm{N}$ removed by denitrification $(\% D)$ was calculated as: 
$\% D=\frac{R_{D}}{R_{T}} \cdot 100$

Data analysis

Data of the two experimental runs were combined because their results were not significantly different (independent samples $t$ test: $t_{21.405}=-0.457$, $P=0.652)$. If necessary, data were $\ln (x+1)$ transformed to achieve homogeneity of variances. Hierarchical nested ANOVA was used to test for effects of vegetation treatment (fixed factor) and light nested within vegetation treatment (random factor) on denitrification rates, nitrate removal, and water column dissolved oxygen. Tukey HSD post-hoc tests were used to test for differences among the individual vegetation treatments. One-way ANOVA was used to test for differences in nutrient concentrations between the three vegetation treatments before the denitrification measurements. Stepwise multiple linear regression was used to test which factors were most important in influencing denitrification rates.

\section{Results}

Conditions in the microcosms

Floating macrophyte cover greatly reduced light irradiance in the microcosms, leading to near dark conditions at the sediment surface (Table 1). Presence of submerged macrophytes also reduced light irradiance in the microcosms, though some light still reached the sediment surface. We observed some periphyton and planktonic algal growth in all microcosms (Table 1).

Nitrate and ammonium were depleted after the 4 week incubation period. After addition of ${ }^{15} \mathrm{~N}[\mathrm{Na}-$ $\mathrm{NO}_{3}$ ] at the start of the denitrification measurements nitrate levels in all treatments were around $1.1 \mathrm{mg} \mathrm{N} /$ 1. Ammonium concentrations were below the detection limit before and after denitrification measurements (Table 1).

The $\mathrm{pH}$ was significantly lower in microcosms covered by floating vegetation than in microcosms without macrophytes (Tables 1, 2, Tukey post-hoc test $P<0.001)$ or with submerged macrophytes (Tukey post-hoc test $P<0.001$ ).

\section{Denitrification rates}

Denitrification rates differed significantly between the treatments (Fig. 2a; Table 2). Denitrification rates in microcosms covered by floating plants were 3.7 times higher than in microcosms without macrophytes (Tukey post-hoc test $P<0.001$ ) and 3.2 times higher than in microcosms with submerged macrophytes (Tukey post-hoc test $P<0.001$ ).

Light tended to have an effect on the denitrification rates within the different vegetation treatments, although this was only significant at the $P<0.1$ level, probably due to the different effects of light for the different treatments. There was no difference in denitrification rates under dark or light conditions in

Table 1 Physical and chemical variables in microcosms with 3 different vegetation types during dark and light conditions measured before $\left(t_{0}\right)$ and after $\left(t_{3}\right) 3 \mathrm{~h}$ denitrification measurements

\begin{tabular}{|c|c|c|c|c|c|c|}
\hline & \multicolumn{6}{|c|}{ Vegetation type } \\
\hline & \multicolumn{2}{|c|}{ No macrophytes } & \multicolumn{2}{|l|}{ Floating } & \multicolumn{2}{|l|}{ Submerged } \\
\hline & Dark & Light & Dark & Light & Dark & Light \\
\hline $\mathrm{NO}_{3}{ }^{-} t_{0}(\mathrm{mg} \mathrm{N} / \mathrm{l})$ & $1.08(0.00)$ & $1.08(0.00)$ & $1.08(0.00)$ & $1.08(0.00)$ & $1.16(0.08)$ & $1.08(0.00)$ \\
\hline $\mathrm{NO}_{3}{ }^{-} t_{3}(\mathrm{mg} \mathrm{N} / \mathrm{l})$ & $1.04(0.02)$ & $0.91(0.08)$ & $0.82(0.09)$ & $0.74(0.02)$ & $0.70(0.16)$ & $0.77(0.08)$ \\
\hline $\mathrm{NH}_{4}{ }^{+} t_{0}(\mathrm{mg} \mathrm{N} / \mathrm{l})$ & $0.00(0.00)$ & $0.00(0.00)$ & $0.01(0.00)$ & $0.00(0.00)$ & $0.01(0.00)$ & $0.02(0.02)$ \\
\hline $\mathrm{NH}_{4}{ }^{+} t_{3}(\mathrm{mg} \mathrm{N} / \mathrm{l})$ & $0.02(0.01)$ & $0.01(0.01)$ & $0.02(0.01)$ & $0.01(0.00)$ & $0.02(0.00)$ & $0.01(0.00)$ \\
\hline $\mathrm{pH}$ & $9.22(0.15)$ & $9.12(0.13)$ & $6.80(0.15)$ & $6.84(0.08)$ & $9.22(0.15)$ & $9.42(0.15)$ \\
\hline Chl-a green algae $(\mu \mathrm{g} / \mathrm{l})$ & $5.13(1.13)$ & $5.54(3.38)$ & $6.89(1.04)$ & $7.98(3.03)$ & $8.33(5.29)$ & $4.88(1.40)$ \\
\hline Light at sediment ${ }^{\mathrm{a}}\left(\mu \mathrm{E} / \mathrm{cm}^{2} / \mathrm{s}\right)$ & & 80 & & 0.5 & & 25 \\
\hline
\end{tabular}

Values given for $\mathrm{NO}_{3}{ }^{-}+\mathrm{NO}_{2}{ }^{-} t_{0}$ are after addition of $1.07 \mathrm{mg} /{ }^{15} \mathrm{~N}\left[\mathrm{NO}_{3}\right]$. Values are given as: mean (standard error) $n=6$ ${ }^{\text {a }} n=1$ 
Table 2 Hierarchical nested ANOVA results comparing different vegetation treatment effects and effects of light nested within the vegetation treatment on denitrification rate, dissolved oxygen, $\mathrm{pH}$ and $\mathrm{NO}_{3}-\mathrm{N}$ removal

\begin{tabular}{|c|c|c|c|c|c|c|c|c|}
\hline & \multicolumn{4}{|c|}{ Vegetation } & \multicolumn{4}{|c|}{ Light in vegetation } \\
\hline & df & MS & $F$ value & $P$ value & $\mathrm{df}$ & MS & $F$ value & $P$ value \\
\hline Denitrification rate & 3 & 55.48 & 46.29 & 0.005 & 3 & 1.20 & 2.48 & 0.08 \\
\hline Dissolved Oxygen & 3 & 52.35 & 1085.97 & $<0.001$ & 3 & 0.05 & 0.94 & 0.719 \\
\hline $\mathrm{pH}$ & 3 & 869.50 & 16827.20 & $<0.001$ & 3 & 0.23 & 1.01 & 0.433 \\
\hline $\mathrm{NO}_{3}-\mathrm{N}$ removal & 3 & 0.67 & 28.34 & 0.011 & 3 & 0.02 & 1.01 & 0.401 \\
\hline
\end{tabular}

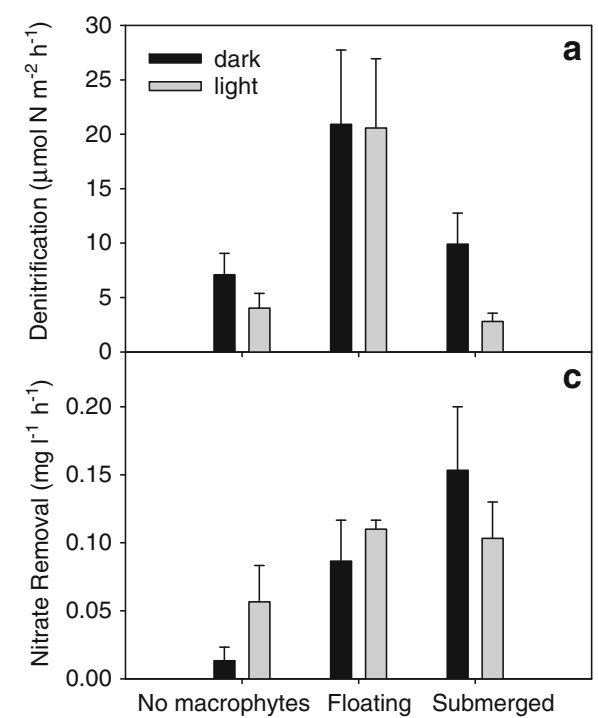

Fig. 2 Total denitrification rates (a), water column dissolved oxygen levels $(\mathbf{b}), \mathrm{NO}_{3}$-removed from the water column during the $3 \mathrm{~h}$ denitrification measurement (c) and $\mathrm{PO}_{4}-\mathrm{P}$ concentrations at the start of denitrification measurements (d) (mean $\pm \mathrm{SE}, n=6$ ) in microcosms without macrophytes,

systems covered by floating plants. However, we found 1.8 times more denitrification under dark conditions than under light conditions in systems without macrophytes and 3.5 times more denitrification under dark conditions than under light conditions in systems with submerged macrophytes.

\section{Water column dissolved oxygen}

Water column dissolved oxygen concentrations differed significantly between the treatments (Fig. 2b; Table 2). Multiple regression analysis including $\mathrm{O}_{2}$, $\mathrm{pH}$, temperature, plant dry weight, plant surface area and chlorophyll- $a$ as explanatory variables showed that $\mathrm{O}_{2}$ was the most important factor explaining denitrification rates (adjusted $R^{2}=0.356$ ). Oxygen

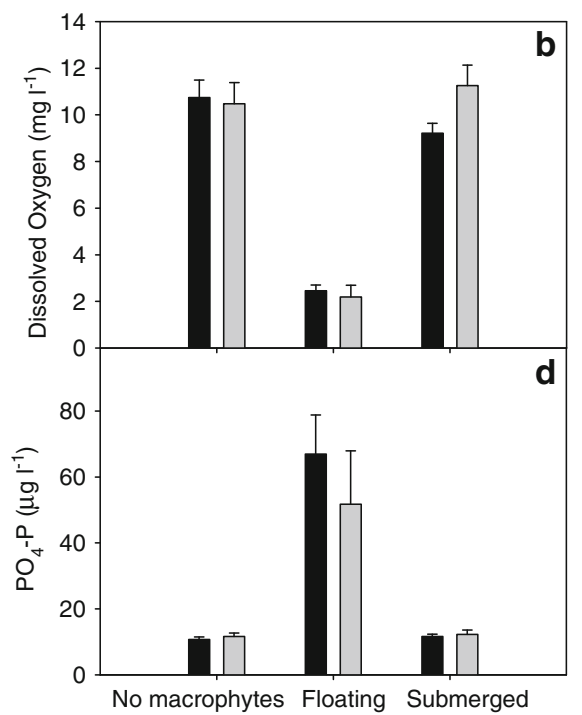

covered by floating macrophytes (L. minor) or filled with submerged macrophytes (E. nuttallii). Black bars show measurements performed under dark conditions, starting after $8 \mathrm{~h}$ of darkness. Grey bars show measurements performed under light conditions, starting after $4 \mathrm{~h}$ of light

concentrations in microcosms covered by floating vegetation were significantly lower than those in microcosms without macrophytes (Tukey post-hoc test $P<0.001)$ or with submerged macrophytes (Tukey post-hoc test $P<0.001$ ), whereas oxygen concentrations in microcosms without macrophytes and in microcosms with submerged macrophytes were similar. Effect of light on water column dissolved oxygen concentration within the treatments was not significant (Table 2).

Nitrate removal and phosphate release

The $\mathrm{NO}_{3}-\mathrm{N}$ removed from the water column during the 3-h denitrification measurements differed significantly between the treatments (Fig. 2c; Table 2). 
Nitrate removal in microcosms without macrophytes was lower than nitrate removal in microcosms with floating macrophytes (Tukey post-hoc test $P=$ 0.035) or submerged macrophytes (Tukey post-hoc test $P=0.004$ ). There were no significant differences between the nitrate removal in microcosms with floating vegetation and microcosms with submerged macrophytes. Effects of light on $\mathrm{NO}_{3}-\mathrm{N}$ removal within the treatments were not significant (Table 2). Only about $6 \%$ of the total nitrate removal could be attributed to the measured denitrification.

After the 4 week incubation period $\mathrm{PO}_{4}-\mathrm{P}$ concentrations in the water column differed significantly between the treatments (One-way ANOVA: $\left.\mathrm{F}_{2}=49.958 P<0.001\right)$. Microcosms covered by floating vegetation had highest $\mathrm{PO}_{4}-\mathrm{P}$ concentrations, whereas those without macrophytes had the lowest $\mathrm{PO}_{4}-\mathrm{P}$ concentrations (Fig. 2d).

\section{Discussion}

Denitrification rates were affected by the presence of macrophytes as well as the type of macrophytes. These effects differed depending on the light conditions. In the dark differences between microcosms were small. However, in the light denitrification in our systems with submerged macrophytes and in those without macrophytes was lower than in the duckweed covered systems. This was likely due to the permanently dark conditions under the duckweed, which inhibited oxygen production by photosynthesis. The floating plant cover also provides a barrier to re-aeration (Morris and Barker 1977).

Our results thus suggest that oxygen production by photosynthesis of microalgae and plants inhibited denitrification in the top layer of the sediment and in biofilms on the macrophyte surface. Such oxygen mediated inhibition of denitrification rates under light conditions was also found in other studies (Christensen and Sorensen 1986; Nielsen et al. 1990; Sündback and Miles 2002).

By contrast, several studies in nitrate-limited systems have found positive effects of illumination on denitrification due to coupled nitrification-denitrification (Laursen and Seitzinger 2004). If nitrate availability is limited, denitrification rates may be largely dependent on the production of nitrate during nitrification. As nitrification requires oxygen, it will be enhanced by photosynthesis (Eriksson and Weisner 1999; Risgaard-Petersen et al. 1994). In our study, coupled nitrification-denitrification is less important because sufficient nitrate was available and ammonium concentrations were low.

Despite the different denitrification rates, overall nitrate removal rates observed during the experiment were similar for all treatments in the light. Denitrification only accounted for ca. $6 \%$ of the nitrate removal. Most of it was probably removed by plant uptake. Both E. nuttallii and L. minor are capable of rapid nitrate uptake from the water column (Cedergreen and Madsen 2002; Ozimek et al. 1993). An uptake rate of $0.1 \mathrm{mg} \mathrm{N} \mathrm{g}^{-1}$ plant dry weight $\mathrm{h}^{-1}$ (Cedergreen and Madsen 2002) would imply that $77 \%$ of nitrate removal in our experiments could be attributed to uptake by plants. In the microcosms without macrophytes, nitrate assimilation by algae may explain part of the nutrient removal during the light period.

It is possible that dissimilatory nitrate reduction to ammonium (DNRA) may have removed some of the nitrate from our systems too. However, DNRA uses more carbon per nitrate than denitrification and will therefore only be favored over denitrification when nitrate becomes limiting (Burgin and Hamilton 2007), which did not occur in our systems. It is therefore likely that denitrification was the dominant pathway for N-reduction in our systems.

Denitrification rates compared to natural systems

Our microcosm setup allowed us to isolate the effects that different functional groups of macrophytes may have on denitrification rates. Rather than distinguishing between denitrification in the water column, biofilm and sediment, we considered effects of macrophytes on the whole system, as effects of macrophytes in the water column may also influence sediment biogeochemical processes. Nonetheless, there are of course profound differences between our microcosms and many natural systems. For example, natural systems have deeper sediments. Therefore, sediment denitrification may play a larger role than in our microcosm experiment. Importantly, if sufficient nitrate is available, denitrification may continue in deeper layers of the sediment even if the upper sediment layers are oxygenated. Also, the degree to which oxygen produced in photosynthesis 
affects denitrification rates will vary with factors such as plant density, respiration rates, and bioturbation (Mermillod-Blondin et al. 2008).

Although denitrification rates in our microcosms were similar to those found in littoral plant covered sediments and mesotrophic lakes (Christensen and Sorensen 1986; Seitzinger 1988), rates observed in agricultural ditches and streams are an order of magnitude higher (de Klein 2008; Smith et al. 2009). The high denitrification in such systems could be due to the fact that they receive very high nutrient loads (Janse and Van Puijenbroek 1998) and also tend to contain large quantities of organic matter (Needelman et al. 2007; Smolders et al. 2006).

\section{Phosphorus release}

Obviously, from a practical nutrient management perspective it is important to consider effects of macrophytes not only on nitrogen but also on phosphorus. Although the low dissolved oxygen concentration under the floating vegetation stimulated denitrification rates, it also reduced the P-binding capacity of the sediment, which led to increased water column phosphorus concentrations. In natural systems this may lead to eutrophication of connected waterbodies. Furthermore, the combined nitrogen removal and phosphorus release may alter the systems chemical stoichiometry, which may affect ecosystem functioning in various ways (Sterner and Elsner 2002).

Our findings illustrate the strong interaction between biota and chemistry in aquatic systems. While increased nutrient loads are a major driver of aquatic vegetation presence and type (Scheffer 1998), our results show that such an alteration of vegetation in turn has profound effects on nutrient dynamics.

Acknowledgments We are grateful to Frits Gillissen and John Beijer for technical assistance, Abdul Mohamed for help with experiments and Jan Vermaat for statistical advice. We thank Andrea Downing, Ingrid van de Leemput, Sabine HiltKörner, and two anonymous reviewers for useful comments on earlier drafts of this manuscript. Funding for this project was provided by STOWA (Dutch Foundation for Applied Water Research) and 14 Dutch water boards (project PLONS).

Open Access This article is distributed under the terms of the Creative Commons Attribution Noncommercial License which permits any noncommercial use, distribution, and reproduction in any medium, provided the original author(s) and source are credited.

\section{References}

Bietz JA (1974) Micro-Kjeldahl analysis by an improved automated ammonia determination following manual digestion. Anal Chem 46:1617-1618

Burgin AJ, Hamilton SK (2007) Have we overemphasized the role of denitrification in aquatic ecosystems? A review of nitrate removal pathways. Front Ecol Environ 5:89-96

Caffrey JM, Kemp WM (1992) Influence of the submerged plant, Potamogeton perfoliatus, on nitrogen cycling in estuarine sediments. Limnol Oceanogr 37:1483-1495

Carpenter SR, Lodge DM (1986) Effects of submersed macrophytes on ecosystem processes. Aquat Bot 26:341-370

Cedergreen N, Madsen TV (2002) Nitrogen uptake by the floating macrophyte Lemna minor. New Phytol 155:285-292

Christensen PB, Sorensen J (1986) Temporal variation of denitrification activity in plant-covered, littoral sediment from Lake Hampen, Denmark. Appl Environ Microbiol 51:1174-1179

Dalsgaard T, Nielsen LP, Brotas V, Viaroli P, Underwood G, Nedwell D, Sundbäck K, Rysgaard S, Miles A, Bartoli M, Dong L, Thornton DCO, Ottosen LDM, Casteldelli G, Risgaard-Petersen N (2000) Protocol handbook for NICE—nitrogen cycling in estuaries. Ministry of Environment and Energy. National Environmental Research Institute, Silkeborg, Denmark

de Klein J (2008) From ditch to delta. Nutrient retention in running waters. Dissertation, Wageningen University

Eriksson PG (2001) Interaction effects of flow velocity and oxygen metabolism on nitrification and denitrification in biofilms on submersed macrophytes. Biogeochemistry 55:29-44

Eriksson PG, Weisner SEB (1996) Functional differences in epiphytic microbial communities in nutrient-rich freshwater ecosystems: an assay of denitrifying capacity. Freshw Biol 36:555-562

Eriksson PG, Weisner SEB (1999) An experimental study on effects of submersed macrophytes on nitrification and denitrification in ammonium-rich aquatic systems. Limnol Oceanogr 44:1993-1999

Green LC, Wagner DA, Glogowski J, Skipper PL, Wishnok JS, Tannenbaum SR (1982) Analysis of nitrate, nitrite, and $[15 N]$ nitrate in biological fluids. Anal Biochem 126: 131-138

Iizumi H, Hattori A, McRoy CP (1980) Nitrate and nitrite in interstitial waters of eelgrass beds in relation to the rhizosphere. J Exp Mar Biol Ecol 47:191-201

Janse JH, Van Puijenbroek PJTM (1998) Effects of eutrophication in drainage ditches. Environ Pollut 102:547-552

Knowles R (1982) Denitrification. Microbiol Mol Biol Rev 46:43-70

Körner S (1999) Nitrifying and denitrifying bacteria in epiphytic communities of submerged macrophytes in a treated sewage channel. Acta Hydrochim Hydrobiol 27:27-31

Laursen AE, Seitzinger SP (2004) Diurnal patterns of denitrification, oxygen consumption and nitrous oxide production in rivers measured at the whole-reach scale. Freshw Biol 49:1448-1458 
Lürling M, Verschoor AM (2003) FO-spectra of chlorophyll fluorescence for the determination of zooplankton grazing. Hydrobiologia 491:145-157

Mermillod-Blondin F, Lemoine D, Boisson J-C, Malet E, Montuelle B (2008) Relative influences of submersed macrophytes and bioturbating fauna on biogeochemical processes and microbial activities in freshwater sediments. Freshw Biol 53:1969-1982

Morris PF, Barker WG (1977) Oxygen transport rates through mats of Lemna minor and Wolffia sp. and oxygen tension within and below the mat. Can J Bot 55:1926-1932

Murphy J, Riley JP (1962) A modified single solution method for the determination of phosphate in natural waters. Anal Chim Acta 27:31-36

Needelman B, Kleinman P, Strock J (2007) Improved management of agricultural drainage ditches for water quality protection: an overview. J Soil Water Conserv 62:171

Nielsen LP (1992) Denitrification in sediment determined from nitrogen isotope pairing. FEMS Microbiol Lett 86:357-362

Nielsen LP, Christensen PB, Revsbech NP, Sorensen J (1990) Denitrification and photosynthesis in stream sediment studied with microsensor and whole-core techniques. Limnol Oceanogr 35:1135-1144

Ozimek T, van Donk E, Gulati RD (1993) Growth and nutrient uptake by two species of Elodea in experimental conditions and their role in nutrient accumulation in a macrophyte-dominated lake. Hydrobiologia 251:13-18

Piña-Ochoa E, Álvarez-Cobelas M (2006) Denitrification in aquatic environments: a cross-system analysis. Biogeochemistry 81:111-130

Reddy KR, Patrick WH, Lindau CW (1989) Nitrificationdenitrification at the plant root-sediment interface in wetlands. Limnol Oceanogr 34:1004-1013

Risgaard-Petersen N, Rysgaard S, Nielsen LP, Revsbech NP (1994) Diurnal variation of denitrification and nitrification in sediments colonized by benthic microphytes. Limnol Oceanogr 39:573-579

Scheffer M (1998) Ecology of shallow lakes. Kluwer Academic Publishers, Lelystad, The Netherlands

Scheffer M, Szabo S, Gragnani A, van Nes EH, Rinaldi S, Kautsky N, Norberg J, Roijackers RMM, Franken RJM
(2003) Floating plant dominance as a stable state. PNAS 100:4040-4045

Seitzinger SP (1988) Denitrification in freshwater and coastal marine ecosystems: ecological and geochemical significance. Limnol Oceanogr 33:702

Seitzinger SP, Harrison JA, Bohlke JK, Bouwman AF, Lowrance R, Peterson B, Tobias C, Drecht GV (2006) Denitrification across landscapes and waterscapes: a synthesis. Ecol Appl 16:2064-2090

Smart RM, Barko JW (1985) Laboratory culture of submersed freshwater macrophytes on natural sediments. Aquat Bot 21:251-263

Smith VH, Tilman GD, Nekola JC (1999) Eutrophication: impacts of excess nutrient inputs on freshwater, marine, and terrestrial ecosystems. Environ Pollut 100:179-196

Smith R, Böhlke J, Repert D, Hart C (2009) Nitrification and denitrification in a midwestern stream containing high nitrate: in situ assessment using tracers in dome-shaped incubation chambers. Biogeochemistry 96:189-208

Smolders AJP, Lamers LPM, Lucassen ECHET, Van Der Velde G, Roelofs JGM (2006) Internal eutrophication: how it works and what to do about it-a review. Chem Ecol 22:93-111

Sterner RW, Elsner JJ (2002) Ecological stoichiometry. The biology of elements from molecules to the biosphere. Princeton University Press, Princeton

Sündback K, Miles A (2002) Role of microphytobenthos and denitrification for nutrient turnover in embayments with floating macroalgal mats: a spring situation. Aquat Microb Ecol 30:91-101

Toet S, Huibers L, Van Logtestijn RSP, Verhoeven JTA (2003) Denitrification in the periphyton associated with plant shoots and in the sediment of a wetland system supplied with sewage treatment plant effluent. Hydrobiologia 501:29-44

van Liere L, Janse J, Arts G (2007) Setting critical nutrient values for ditches using the eutrophication model PCDitch. Aquat Ecol 41:443-449

Weisner SEB, Eriksson PG, Graneli W, Leonardson L (1994) Influence of macrophytes on nitrate removal in wetlands. Ambio 23:363-366 